\title{
The Penetration of Technocratic Logic into the Educational Field: Rationalizing Schooling from the Progressives to the Present
}

\section{Citation}

Mehta, Jal. 2013. The Penetration of Technocratic Logic into the Educational Field: Rationalizing Schooling from the Progressives to the Present. Teachers College Record 113 (5): 1-40.

\section{Published Version}

http://www.tcrecord.org/library/abstract.asp? contentid=16947

\section{Permanent link}

http://nrs.harvard.edu/urn-3:HUL.InstRepos:33063309

\section{Terms of Use}

This article was downloaded from Harvard University's DASH repository, and is made available under the terms and conditions applicable to Open Access Policy Articles, as set forth at http:// nrs.harvard.edu/urn-3:HUL.InstRepos:dash.current.terms-of-use\#OAP

\section{Share Your Story}

The Harvard community has made this article openly available. Please share how this access benefits you. Submit a story.

Accessibility 


\title{
The Penetration of Technocratic Logic into the Educational Field: Rationalizing Schooling from the Progressives to the Present
}

\author{
Jal Mehta \\ Harvard Graduate School of Education
}

Final Pre-Publication Version

2013

\begin{abstract}
Official citation:
Mehta, Jal. "The Penetration of Technocratic Logic into the Educational Field: Rationalizing Schooling from the Progressives to the Present." 2013. Teachers College Record 113 (5): $1-40$.
\end{abstract}




\title{
The Penetration of Technocratic Logic into the Educational Field: Rationalizing Schooling from the Progressives to the Present
}

\begin{abstract}
:
Educational accountability is not a recent invention. Over the course of the $20^{\text {th }}$ century, there were three major movements demanding accountability in American education: the efficiency reforms of the Progressive Era, the now almost forgotten movement toward accountability in the late 1960s and early 1970s, and the modern standards and accountability movement, culminating in No Child Left Behind. This paper considers the three movements as cases of school "rationalization" in the Weberian sense, in that each sought to reduce variation and discretion across schools in favor of increasingly formal systems of standardized top-down control. This impulse to rationalize schools cannot be explained by interest group or partisan explanations, as those that have purveyed the reforms defy easy ideological generalization. Instead, these reforms can be understood as a process of penetration of a "technocratic logic" into the educational sphere. In each case, this process exhibited a similar pattern: 1) the creation of a crisis of quality which destabilized the existing educational status quo; 2) the elevation of a technocratic logic, backed by the knowledge base of a high status epistemic community; 3) the rallying of ideologically diverse powerful actors external to the schools behind a commensurating logic that promised control and improvement over an unwieldy school system; and 4) the inability of the education field to resist (and often to be co-opted by) this technocratic logic, due to its historical institutionalization as a highly feminized, weak, bureaucraticallyadministered field lacking its own set of widely respected countervailing professional standards. Implications suggest that unless teachers are able to develop and organize themselves as a stronger field, they will remain at the whim of external actors; professionalization may also produce better outcomes than the repeated emphasis on rationalizing reforms.
\end{abstract}




\section{The Penetration of Technocratic Logic into the Educational Field: \\ Rationalizing Schooling from the Progressives to the Present}

Educational accountability is not a recent invention. Over the course of the $20^{\text {th }}$ century, there were three major movements demanding accountability in American education: the efficiency reforms of the Progressive Era, the now almost forgotten movement toward accountability in the late 1960s and early 1970s, and the modern standards and accountability movement, culminating in No Child Left Behind. This paper considers the three movements as cases of school "rationalization" in the Weberian sense, in that each sought to reduce variation and discretion across schools in favor of increasingly formal systems of standardized top-down control. This impulse to rationalize schools cannot be explained by interest groups or partisan cycles, as those that have purveyed the reforms defy easy generalization.

This paper offers an alternative explanation, rooted in the penetration of a "technocratic logic" into the educational sphere. In this view, education is a weak professional field, susceptible to declarations of crisis that undermine the ability of its professional stewards to retain control over its ends and means. At three different times in the nation's history, ideas of scientific management from other fields, particularly business, have penetrated the educational sphere and shaped leading reform movements. In this paper I break this process into four stages,

exploring in each case the sources of these educational crises, the reasons behind the importing of technocratic logics from other fields, how such technocratic logics picked up an array of influential political backers, and, finally the inability of educators to resist these external logics. The combination of the nation's longstanding high regard for business methods and values, the seemingly perpetual crises of quality of schooling, and the weak organization of the teaching 
profession has again and again resulted in the insertion of external logics that promise to rationalize the educational field.

The implications of this analysis are that while we often analyze school reform in terms of the effects of this or that program, in a broader view it may be the way that the entire sector is organized that is problematic. From this perspective, the choice to organize teaching into a bureaucratically-administered hierarchy, where teachers' role is to implement programs derived by others, rather than a profession, wherein members of the field take responsibility for assuring a common standard of quality practice, has had enduring consequences. It has made the kind of principal-agent logic that characterizes accountability regimes seem repeatedly alluring, despite the well-known limitations of this approach (Pressman and Wildavsky 1973, Elmore 2004, Cohen and Moffitt 2009). And it has left educators vulnerable to outsiders seeking to rationalize the field, despite the fact that their methods are often insufficient to produce improved educational outcomes. Emerging international evidence is beginning to suggest that nations which outpace the United States have stronger professions and have organized their sectors more around professional than hierarchical accountability (Tucker and Schleicher 2010), which may be a more promising path towards large-scale improvement.

\section{THREE ERAS OF RATIONALIZING SCHOOLING}

In the Progressive Era, a group of reformers comprised mostly of businessmen, city elites, and university professors sought to shift power from large local ward boards that they saw as parochial and unprofessional to smaller boards controlled by professional elites. They empowered the superintendent as the "CEO" of the school system, and directed him to use the latest in scientific methods and modern management techniques to measure outcomes and ensure 
that resources were being used efficiently to produce the greatest possible bang for the buck. The newly emerging science of testing was used widely to ensure that teachers and schools were up to standards and to sort students into appropriate tracks, with the aim of "efficiently" matching students with the curriculum appropriate to their ability.

In the late 1960s and early 1970s, a second accountability movement took hold of American schooling, this time at the state level. Seeking to realize both a civil rights agenda of improving the quality of schooling and to satisfy more conservative concerns about the efficient spending of public dollars, no fewer than 73 laws were passed between 1963 and 1974 seeking to create standards or to utilize a variety of scientific management techniques to improve schooling. Frequently overlooked by educational historians in favor of more prominent movements around desegregation and open schooling, the template that developed largely under the radar in the late 1960s and early 1970s would prefigure the modern movement towards school accountability.

Given this backdrop, the current standards and accountability movement is in fact the third such movement of the century. Launched initially by the famous A Nation at Risk report in 1983, a standards movement swept the states in the 1980s and 1990s before becoming part of federal law in the 1994 and 2001 reauthorizations of the Elementary and Secondary Education Act (the 2001 reauthorization became known as No Child Left Behind). As we will see, many of the objections to NCLB - too much testing; testing narrows the curriculum; the law unfairly holds school accountable for events outside their control-are almost exact replays of the criticisms of accountability movements earlier in the century.

These three movements $(1900$ - 1920, 1963 - 1974, and 1983 - present) share certain features of organizational rationalization. ${ }^{1}$ In the name of efficiency, all three movements sought to reduce the variation among schools in favor of greater centralized standardization and control, 
hallmarks of the rationalizing process. Power shifted upwards, in each of the cases, away from teachers and schools and towards centralized administrators. ${ }^{2}$ Similar conceptions of motivation underlay the three sets of reforms, each using some version of standards and testing to incentivize teachers to do their bidding. Each of the movements prized quantitative data, and

elevated a scientific vision of data-driven improvement over a more humanistic view of educational purposes. Despite the differences in time periods, the essence of the rationalizing vision has remained remarkably unchanged.

There are at least two ways to think about these repeated bouts of rationalizing reforms. One is as three distinct episodes, each of which had their own precipitating events, lead actors, and key ideas. The question from this perspective is about whether there are similar patterns across these episodes, or similar sets of factors which tend to precipitate or sustain them. A second way is to see them as part of an unbroken trajectory; here the question is less about what prompts each of them, and more about whether there is something which makes American school reform continuously inclined towards accountability centered approaches. I take up both questions in the space below.

\section{The Usual Suspects: Interest Groups, Partisan CyCles, and Value Conflicts}

These repeated efforts to impose accountability on schools are not easily explained by conventional theories. Consider interest group explanations. Looking across the cases, an almost bewildering array of actors have been important in championing the reforms: good government reformers and schools of education in the Progressive Era, state departments of education, state legislators, and taxpayers groups in the 1960s/1970s reforms, and governors, presidents, state and federal legislators, foundations, business groups, and civil rights groups in the most recent 
round of reforms. Business groups, who might be the most natural suspect given the character of the reforms, played a secondary role to governors in the contemporary reforms (see Author 2006 for more details), and were not a central factor in the 1960s reforms. Schools of education, who were critical champions of the Progressive Era reforms have frequently been critics of the most recent accountability movement. In short, while various powerbrokers have been involved in each of the reforms, there is no group that has repeatedly been the champion of school accountability efforts.

There also have not been clear partisan patterns in movements for school accountability. Tyack and Cuban (1995: 45) note that, in contrast to other countries, in the United States "at any one time Democratic and Republican parties have not differed very much in their views of education even if they had quite different policies in other domains." This more general pattern seems to apply similarly to accountability policies — in each era members of both parties were supportive of the reforms, if not always for exactly the same reasons. In the Progressive Era, members of both parties pushed for control of schools to be put in the hands of centralized professional administrators. In both the 1960s/1970s and in the present, liberals supported accountability as a mechanism for improving school quality for high poverty students, while conservatives were attracted by its ability to monitor the efficiency of spending of public dollars. ${ }^{3}$ In part because of this bipartisan support, accountability and standards have been able to flourish regardless of which party was in power, most recently in the championing of standards first by President Clinton and then by George W. Bush. In each era, the key question is not which party pushed the reforms, but how politicians of both parties came to see accountability as the promised path to school improvement. 
Tyack and Cuban (1995: 41) offer a third view of the reasons for cycles of policy talk. Their view is that these cycles are "an inevitable result of conflict of values and interests built into a democracy system of school governance and reflecting changing climates of public opinion. People are constantly criticizing and trying to improve public education. From time to time, worries about society and schooling so accumulate the widespread educational reform ensues." This view, while plausible, is couched at such a high level of generality that it is almost not falsifiable. Perhaps this is unavoidable in trying to offer a workable theory that would encompass all of the pendulum swings in American education. When considering a more specific set of reforms, such as the recurring interest in testing and accountability, a more specific theory can be hazarded.

\section{An Alternative VieW: The Power of Ideas and the Weakness of the Educational Field}

The limits of these approaches suggest a need for a different explanation. The argument that follows advances a cultural approach that draws upon two literatures-one in political science and one in sociology — to develop an argument about how and why rationalizing schools has seemed repeatedly alluring.

From political science, the argument draws on the literature on the power of ideas or paradigms in the policy process (Hall 1989, 1993, Berman 1998, Campbell 2002, Beland and Hacker 2004, Author 2010, Davies 1999, 2002). These literatures have emphasized the ways in which how a problem is defined (Rochefort and Cobb 1994) is critical to understanding how the politics of an issue play out. In other work, I have argued that "paradigms can shape politics" (Author 2012, see also Baumgartner and Jones 1993), meaning that once a problem is defined, it has the power to shape a policy domain, shaping what solutions are seen as desirable and who 
participates in the subsequent debate. Ideas are particularly well-suited to explaining change (or in this case multiple episodes of change) because different views of a problem are constantly swirling, and when one achieves particular salience, it can fairly rapidly spark a series of interrelated developments, leading to significant change in a relatively short period of time.

Important to this ideational approach is the way in which successful ideas resonate with the broader cultural context in which they are placed (Ferree et al. 2002). In the case of the logic of managerial accountability, reformers have benefitted from the association with leading business methods and more generally the high regard for business in American life (Hofstadter 1963). We will also see that the two more successful movements - in the Progressive period and from 1980 to the present — have not coincidentally corresponded with two moments in American history in which business was highly venerated.

From sociology, the argument builds on the literature about fields and professions. Pierre Bourdieu (Bourdieu and Wacquant 1992) has conceptualized society as a series of fields, with each seeking to develop and extend its logic into other fields. Similarly, Andrew Abbott's (1988) work has seen professions as competing with one another for jurisdictional control. This work builds on those traditions, and seeks to link them more directly to politics, suggesting that the way in which a field institutionalizes directly affects its social, cultural, and political power, and thus the degree of respect it garners from other actors. If the power of ideas helps to explain bursts of activity in educational reform, the failed professionalization of teaching explains the continuity in the nature of what is proposed and the recurring inability of educators to resist external reforms.

With these perspectives as background, an examination of the data suggests that across eras movements to impose school accountability follow a remarkably similar process by which a 
"technocratic logic" comes to penetrate the educational field: 1) the declaration of a crisis of quality which destabilized the existing educational status quo; 2) the elevation of a "technocratic" institutional logic, backed by the knowledge base of a high status epistemic community, that resonated with the broader climate of the times; 3) the rallying of ideologically diverse powerful actors external to the schools behind a commensurating logic that promised control and improvement over an unwieldy school system; and 4) the inability of the education field to resist (and often to be co-opted by) this technocratic logic, due to its historical institutionalization as a highly feminized, weak, bureaucratically-administered semi-professional field lacking its own set of widely respected countervailing professional standards. The ideas and professions lenses are connected in that the way that the field is structured-as a public bureaucracy with a weak profession-makes the ideas of rationalization from above seem repeatedly attractive.

By technocratic logic, I mean technical theories of how to make systems function more efficiently. Technocratic solutions differ from political solutions, which emphasize the inherent tradeoffs in different policy choices. While in some sense all policies are political, technocratic solutions promise improved performance through gains in efficiency, effectively masking the need for distributive tradeoffs. Technocratic solutions also differ from domain-specific approaches (in this case education-specific approaches), in that the essence of their logic draws not on knowledge drawn from the sector, but rather applies more general principles of management to the sector under consideration. For example, ideas about how to teach reading that are grounded in research on reading or notions of how to run a discussion that are based in the properties of good discussion are approaches that are grounded in field-specific knowledge and practice rather than a broader technocratic logic. 
This set of lenses raises a different set of questions and implications which I return to in the discussion and conclusion. From this viewpoint, what is at stake in the struggle over school accountability is the autonomy of the educational field from experts from other fields who seek to import a logic of data-driven organizational rationalization (the techonocratic logic) into the educational sphere (on logics see Friedland and Alford 1991). Below we consider questions of why this technocratic logic has been so popular, but also why the educational sphere has been largely unable to resist, which, I argue, relates to the weak way that the profession was historically institutionalized.

The penetration of a logic into a field raises a different set of considerations than the jurisdictional competition perspective originated by Abbott (1988). In jurisdictional competition, two sets of claimants are seeking to do the work of a sector of human activity, such as the competition between psychiatrists and psychologists or between shamans and doctors. In contrast, when the case is about the penetration of an external logic into a field, there is no prospect that the practitioners in the field will suddenly be replaced en masse by outsiders. What is at stake is subtler but no less significant: that the standards of the field and the activities within the field will gradually be transformed into a metric that is foreign to the internal standards or practice of the field (MacIntyre 1981).

\section{Cyclical Patterns: Crisis Identified, External logic Promises a Solution, Political Actors Rally in Support, Teachers UnAble to Resist}

The PROGRESSIVE ERA: CREATING THE Foundation FOR RATIONALIZATION

The first movement to accountability came in the Progressive Era. Muckraking journalists framed the problem and provided the impetus for action. The initial spark came from Joseph Mayer Rice's exposé of school practices in 1892. Rice, a doctor by training, traveled to 
schools in 36 cities over the course of six months, and published a nine-part series in The Forum criticizing the dullness of recitation as a method of learning and the failure of superintendents to introduce more effective pedagogical methods to the classroom. Rice reserved much of his outrage for teachers, who he saw mainly as incompetents who had gained their positions through patronage. To these criticisms he added a comparative research method that sought to explain why third grade reading and math were taught more effectively in some schools than in others. In the two decades that followed, many of the themes that Rice had initially championed were repeated by other muckrakers, and the idea that the schools were inefficient and corrupt was widely repeated in the low-price popular magazines, whose combined circulation by 1905 was 5.5 million. $^{4}$

In education reform, as in other fields, the muckrakers played a critical role in spurring action. Richard Hofstadter has argued that "to an extraordinary degree the work of the Progressive movement rested upon its journalism." 5 For example, in the legislative fight over centralization in New York a senator cited Rice's indictment of the school system to demonstrate that the results "were far below the standard in other cities; that the methods employed in the classroom were nothing short of 'dehumanizing'; that the whole system was not only antiquated but actually pernicious. ${ }^{\prime 6}$ Reformers also used other critiques of schools to their advantage, such as Leonard Ayres study of "retardation" in the schools ${ }^{7}$ and the dismaying results of army IQ tests. ${ }^{8}$ David Tyack's work on centralizing education reforms in four cities reaches the following conclusions about the patterns of reform: "Like reforms in public health, city government or police and welfare work, urban educational reform followed a familiar pattern of muckrakers' exposure of suffering, corruption, or inefficiency; the formation of alliances of leading citizens 
and professional experts who proposed structural innovations; and a subsequent campaign for 'non-political' and rational reorganization of services."9

With the problem defined as inefficiency and variation in performance, it was not surprising that Taylorism appeared as an attractive solution. The Taylor system of industrial management hit the public eye in 1910 , with a promise to increase efficiency, raise profits and eliminate waste through a careful accounting of the costs and productivity of the various components of the production process. Perhaps the most famous manifestation of the efficiency movement was in the time-motion studies, which sought to capture in minute detail the differences between more and less effective workers, and to use these findings to boost productivity.

Applied to the school system, scientific management meant an increased focus on cost accounting, empowering superintendents to use their discretion to increase the productivity of teachers and the system as a whole, and using measurement and testing to compare, improve and standardize practice across districts. One prominent strand of accountability, then as now, is its focus on financial accounting. This took the familiar form of demands for improved record keeping, but it also took more novel forms, such as the system proposed by Newton, Massachusetts superintendent Frank Spaulding and Chicago professor Bobbitt to calculate the costs that school districts were spending per subject per hour. Spaulding claimed, for example, that he didn't know whether music was more valuable than Greek, but that he knew that Greek cost more than music, and was therefore a far less efficient use of resources. ${ }^{10}$ Bobbitt conducted a survey of 25 high schools in seven states and used the data to specify the range of costs appropriate for a given subject; he excoriated the schools that fell above that range and hence were wasting valuable taxpayer money. 
It was a short step from financial accounting to arguing (exactly as is argued today) that schools needed to be held accountable for the results they produced. The answer, as it was laid out by Bobbitt, was to create a system that was at the time an adaptation of the Taylor system and would look much like what we call today standards-based reform. The first stage was for standards to be set externally to the school itself. Standards would serve both as a goal against which success could be measured and as a way of motivating schools to higher levels of performance. A second stage was measuring whether the students had achieved the standards. This could be accomplished through testing (standardized mathematics tests and handwriting scales were particularly popular standardized tests in use at the time), or simply through accurate accounting, such as counting the number of mathematical calculations that an $8^{\text {th }}$ grader could complete in a minute with a given level of accuracy. In Bobbitt's view, with goals clarified and a system of measurement in place, the teacher can know "whether she is a good teacher, a medium teacher or a poor teacher," and supervisors would have "incontestable evidence of inefficiency against the weak teacher who cannot or refuses to improve." ${ }^{11}$

The recommendations of Bobbitt and Edward Cubberley, a Stanford education professor who was another prominent advocate of reform at the time, were widely adopted, particularly in the large cities. National Education Association meetings, the primary gathering point for educators at the time, were increasingly full of discussions of efficiency in education, with titles like "By What Standards or Tests Shall the Efficiency of a School or System of Schools Be Measured?" By March 1913, the American School Board Journal reported that teacher rating scales were used "almost without exception" in large cities. Edward Thorndike of Columbia's Teachers College had devised standard tests to evaluate students' achievement in reading, math, spelling, handwriting and other school subjects, and in 1921 educational sociologist Ross Finney 
reported that "at the present time scales and tests are used in all but unprogressive schools everywhere." As of 1916, Cubberley reported that efficiency bureaus, which coordinated teacher and student testing, had been established in Boston, New York, New Orleans, Detroit, Kansas City, Rochester, and Oakland; by 1934 about 60 of the larger systems had adopted the school research bureaus. ${ }^{12}$

The political success of the efficiency movement rested in part on how its assumptions were consistent with prevailing cultural assumptions of the times. In the years between 1910 and the Great Depression, when the status of business was at perhaps an all-time high, the scientific efficiency models were spread widely through popular newspapers and magazines, and were applied to everything from farms to families to churches. ${ }^{13}$ Science and efficiency seemed to provide a way to instill order in a period of rapid change spurred by massive industrialization and immigration. As Herbert Kliebard has written, "Of the varied and sometimes frenetic responses to industrialism and to the consequent transformation of American social institutions, there was one that emerged clearly dominant both as a social ideal and as an educational doctrine. It was social efficiency, that, for most people, held out the promise of social stability in the face of cries for massive social change, and that doctrine claimed the now potent backing of science in order to ensure it."14

Such a climate heavily tilted the playing field in favor of the reformers, creating the politics needed to move and sustain the accountability movement. On the one side were an elite comprised of "good government" reformers, foundations, business elites, university presidents, and professors of education, who sought to take a localized and highly varied system of schooling and transform it into what Tyack (1974) famously called "the one best system." These "administrative progressives" sought to wrest control away from a ward-based system of local 
politics that seemed to reformers to be resistant to newly developing models of scientific management and efficiency. The reformers sought to concentrate administrative power in the superintendent, a figure that they thought should resemble the chief executive officer of a business, and oversight power in a small, ostensibly "non-political" school board, largely comprised of themselves or other men of similar class background. In these aims they were quite successful, as the average size of school boards in large cities was reduced from an average of 21.5 in 1893 to 10.2 in 1914 to a median of seven by 1923. Both case studies and larger-scale investigations suggest that school boards after centralization were largely composed of business and professional men. ${ }^{15}$

The reformers faced significant opposition on both political and intellectual grounds. In their goals of "removing schools from politics" and centralizing authority in city elites, not surprisingly they faced opposition from the local wards who were losing power in the centralizing wars. These divisions between city elites and community locals often mirrored divides between classes and between WASPs and immigrant Catholics; the less powerful groups in these disputes were not impressed by the claims of the "professionals" to be removing school administration from politics. As the battles raged city by city to consolidate school boards in the hands of business and political elites, opposition from teachers, labor unions, and other local constituencies was significant and sometimes victorious. ${ }^{16}$

The desires of reformers, particularly school boards and superintendents, to standardize, measure, and direct the work of teachers and students through systems of testing and accountability also received political and intellectual criticism. Teachers, for reasons both selfinterested and philosophical, resented their loss of autonomy, the influence of outsiders in criticizing and rating their work, and the imposition of a factory model onto the process of 
learning. Centralizing movements were one impetus for early teacher organizing in Chicago and elsewhere. ${ }^{17}$ The American Teacher, the official journal of the American Federation of Teachers, printed the following message on its front page in March 1916: "If efficiency means the demoralization of the school system; dollars saved and human materials squandered; discontent, drudgery and disillusion—we'll have none of it!” As one articulate teacher opposing the reforms put it in a 1912 issue of American Teacher, the efficiency reforms represented the commercialization of education: "We have yielded to the arrogance of 'big business men' and have accepted their criteria of efficiency at their own valuation, without question. We have consented to measure the results of educational efforts in terms of price and product - the terms that prevail in the factory and the department store. But education, since it deals in the first place with organisms, and in the second place with individualities, is not analogous to a standardizable [sic] manufacturing process. Education must measure its efficiency not in terms of so many promotions per dollars of expenditure, nor even in terms of so many student-hours per dollar of salary; it must measure its efficiency in terms of increased humanism, increased power to do, increased power to appreciate." 18

However, then as now, ultimately the reformers were victorious, for reasons that are consistent with the idea-centered theory laid out above. The muckrakers framing of the crisis as one of inefficiency and lack of standardization in process and outcome paved the road for Taylorism. Taylorism was attractive because it emanated from a higher status field, sought to standardize schooling, and was consistent with a broader cultural regard for business methods and values. This framing of the problem brought in a wide variety of powerful allies within cities, who sought to empower superintendents to be the educational equivalents of captains of industry. Resistance thus was limited to the non-professional class and to teachers, who were 
ultimately no match for these reformers, who had both greater political power and a solution that was consistent with the framing of the problem. Later accountability movements would both mirror many of these patterns and build upon the district-level pattern of rationalization that was created by these Progressive Era reformers.

The 1960s And 1970s: The NAscent State AcCountability Movement; The Bridge to the PRESENT

A second accountability movement emerged four decades later, again following mounting criticisms of the schools, this time at the state level. Two strands of criticism were prominent: one focused on whether schools were performing basic functions; the other on whether the schools were meeting their responsibilities to poor and minority children. Bestsellers like Arthur Bestor's Educational Wastelands: The Retreat from Learning in our Public Schools (1953) and Rudolph Flesch's Why Johnny Can't Read (1955) bemoaned the excesses of pedagogically progressive education, and urged a return to basics like phonics and standards. The launching of Sputnik in 1958 seemed to validate these critics, and led almost immediately to an increased emphasis on math and science education. Meanwhile, civil rights advocates, beginning with Brown v. Board of Education and continuing through the civil rights movements of the 1960s were pointing to the ways that schools had traditionally not served minority students. The passage of the Elementary and Secondary Education Act in 1965 began to address some of these concerns, and also prompted legislators such as Robert Kennedy to ask whether the new programs were going to achieve the results they intended. ${ }^{19}$

Further focusing attention on the discrepancy between programs and results was the release of the "Coleman report" in 1966. Commissioned by the U.S. Office of Education in accordance with the Civil Rights Act of 1964, the study was expected to show that differences in 
the resources available to minority students would explain the differences in outcomes between them and more advantaged students. Instead, the report found that differences in outcomes were more attributable to differences in family background and peer composition than to school resources per se. The study has been called the "most significant educational study of the $20^{\text {th }}$

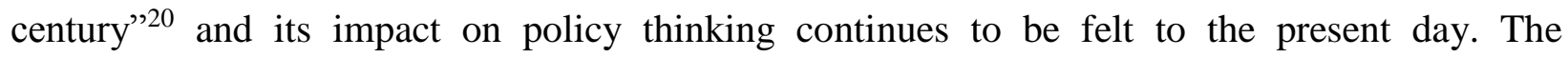
significance of the report, as Coleman himself noted in an essay five years after its release, is that it "has had its major impact in shifting policy attention from its traditional focus on comparison of inputs (the traditional measure of school quality used by school administrators...) to a focus on output, and the effectiveness of inputs for binging about change in output." 21 The accountability movement that would emerge in the years that followed took this disjuncture as its raison d'etre, seeking to ensure that school spending would efficiently lead to better outputs. While the crisis in the Progressive Era was identified by muckraking journalists, in the 1960s it was the publication of a social scientific report that focused attention on the gap between inputs and outputs.

With this production function frame set, a technocratic logic emerged again, this time from the Department of Defense. The Defense Department had initially pioneered many of the techniques which would come to be associated with rationalizing education. Building on the district-level accountability movements created in the Progressive Era, the goal this time around was to extend the reach to the state level, seeking to develop state-wide goals, assessments, and accountability systems. A review of the literature in 1974 found that the educational accountability movement had generated more than 4,000 books and articles on the subject, many of them "how to" works on how to introduce these techniques into education. ${ }^{22}$ At least 73 state laws seeking to create educational accountability were passed and an analysis of these laws 
suggested that they featured the following techniques of scientific management: planning, programming budgeting systems (PPBS), management-by-objectives (MBO), operations analysis, systems analysis, zero-based budgeting, and program evaluation and review technique (PERT), among many others. ${ }^{23}$ Generally speaking, the aim was to identify learning objectives, collect data on the fulfillment of these objectives, evaluate the role that each part of the system was playing in achieving these objectives, and to both exert pressure on schools and reallocate funding in the hopes of producing better results. U.S. Office of Education Associate Commissioner Leon Lessinger, who was perhaps the most well-known proponent of educational accountability in the early 1970s, outlined the rationale for accountability in terms highly reminiscent of Taylorism: "Once we have standardized, reliable data on the cost of producing a variety of educational results...our legislators and school officials will at last be able to draw up budgets based on facts instead of on vague assertions. Through knowledge gained in the process of management, we will also be able to hold the schools accountable for results." 24

Like Bobbitt before him, Lessinger also saw in industry a model for reform. He writes, "In business we judge the effectiveness of a firm by its profit, by investment return, and by other financial indicators. In a non-profit agency such as a school, we judge its effectiveness according to the benefits experienced by its clients (or in the case of education, its students)." Resisting claims that professional knowledge or expertise should insulate educators from the judgment of outsiders, Lessinger asserts that professionals are judged by one standard-results: "Ultimately there is only one test rest of professional competence: proof of results. For example, if an attorney loses as many cases as he wins, he will soon have none but the most ignorant impecunious clients. Neither special education nor experience by itself validates his claim to special wisdom." Channeling Bobbitt and Spaulding, Lessinger advocated for a measure that 
would allow managers to evaluate the costs of educating a student per year per subject: "For example we do not know what the average cost of increasing a youngster's reading ability by one year is: all we know is what it costs to keep him for one year with a textbook and a teacher... It would make much more sense if we moved from the concept of per-pupil cost to the concept of learning-unit cost, and focused on the cost of skill acquisition rather the cost of maintaining children in schools. ${ }^{25}$

The model of change shared Taylorist assumptions of schools as primarily organizational entities that could be engineered for higher productivity. Thomas James, an astute critic of the 1960/1970s accountability reforms, wrote in 1968 that a "new cult of efficiency" was emerging paralleling the Progressive Era reforms. James highlighted the role of efficiency experts at the Defense department, and then argued that a "newer priesthood of economist and political scientists" had "joined the engineers in advising government about improving schools... The models they use are, like those of engineers adapted from among those long used to describe physical, mathematical, and mechanical relationships.” 26

Again the opposition to the reforms came from teachers and humanistic educators. Teachers argued that accountability measures unfairly evaluate them for outcomes only partially under their control, and that an emphasis on testing would narrow the curriculum and would undermine important educational goals. An article in the New York Times published in 1974, “Accountability Plan Angers Teachers, With Many Foreseeing Threat to Jobs" quoted a range of teacher objections to accountability plans. A teacher union representative in Ohio argued that unless certain conditions were met, "we don't have enough control over the situation to be held accountable for the final product." The NEA commissioned a study denouncing a Michigan accountability program as "ill-conceived" and "counter-productive." Meanwhile, Del Gardner, a 
teacher in Bakersfield, California, said that an accountability program in his district had gotten "the teachers...so involved with testing...that they had little time for anything else. It was a misuse of testing and a misunderstanding of what accountability is all about." ${ }^{27}$

While teachers rebelled against how testing affected their daily lives, some educators were more concerned with the effect on accountability programs on the shape of education as a whole. In an essay titled "Accountability from a Humanist's Point of View," C.A. Bowers of the University of Oregon warned that accountability movements played to populist views and risked that schools, rather than fostering students' abilities to think critically, would simply respond to the most powerful segment of the public. In terms very similar to the 1912 critique of Taylorism, Bowers argued:

"I suspect that another reason the advocates of accountability have not talked about education as an intellectual experience is that they have committed themselves to a quantitative system of measurement. There is some usefulness in knowing the rate at which a person can perform a skill. But I am not sure that we can measure objectively and quantitatively what a students learn in the social sciences and humanities unless they are rendered lifeless by being reduced to names, dates, and places... Educational measurement encourages teachers to offer a simplistic view of life, conditions students to look for the right or wrong answer without doing the hard work of thinking and wrestling with ambiguities, and allows the educator to maintain the illusion that he is conducting his enterprise on a scientific basis." 28

What differentiates the second movement from the earlier and later ones is that it was only partially successful. States did pass laws to create assessments and thousands of books and articles were written about educational accountability, but the outcome was not the remaking of schools and systems evident in the Progressive Era and the present. The most detailed evidence on this state standards movement comes from a series of reports by the Educational Testing Service and a consortium called the Cooperative Accountability Project. ${ }^{29}$ The picture that emerges is an early phase of a standards-based package. As of 1973, there were 42 state testing programs in 33 states, but most tested only in one or two grades. ${ }^{30}$ A section of one of these 
reports titled "what's happening with educational accountability" found that states had consistently completed the early, more informational, steps of the accountability model (developing objectives, conducting a needs assessment) but had not moved to the later, more contentious, aspects of the model (making consequential decisions on the basis of measured results). The activities in the states corresponded to this division: 38 states determined desired outcomes and 44 states conducted a needs assessment; but no states fully implemented a model that moved all the way to using data for consequential decision-making. ${ }^{31}$

Why was this movement less successful than the one that preceded it and the one that followed? Consistent with the explanation developed above, in this case the precipitating crisis and proposed solution were not able to mobilize a sufficient array of political backers to move the agenda. While governors, legislators and courts were consumed by highly visible fights over divisive issues like desegregation and community control, the standards movement was mostly a project of good government officials within state departments of education. Standards, and particularly, accountability in this period were delimited by the inability of proponents to, in E.E. Schattschneider's term, widen the conflict and create significant political momentum behind the proposed reforms. ${ }^{32}$ Survey evidence suggests 29 of the state programs were initiated by State Departments of Education; the legislature was initiating actor in only 5 states, and in 8 states it was a combined effort across multiple actors, often including the State Department of Education. The funding for these programs came largely from the federal government or jointly from the federal and state governments, and only rarely from the state governments. ${ }^{33}$ It is perhaps not surprising that state accountability systems which were largely initiated by State Departments of Education and paid for by the federal government were unable to gain more traction, as they frequently had neither political nor financial support from the states that in theory were 
sponsoring them. While teachers unions consistently opposed these reforms and put considerable resources into defeating them, no similarly powerful group spoke up in their favor. ${ }^{34}$

It is also worth noting that the "climate of the times" in the late 1960s was not as favorable to accountability logics as the Progressive period or the more recent one. Notions of free schooling and even deschooling were at their height, ideas which were the antithesis of the kind of ordered schooling that standards and accountability proponents envisioned. At the same time, movements to desegregate schools or give communities greater control over them also generated much greater political passion during this period than staid visions of more efficiently administered schooling.

Overall, the contours of the second accountability movement resembled the earlier and later ones in a number of key respects: a crisis that defined the problem as a need to improve the relationships between inputs and outputs; proponents who argued that the benefits of data, quantification, and objectivity could create standardization across an unwieldy school system; and critics who argued that the measurable was crowding out the meaningful and that managerial systems from above were likely to alienate those actually doing the work in schools. The one major difference between this movement and the ones that came earlier and later is that it was not the most powerful reform movement in its own time. It was clearly overshadowed by explosive nation-wide battles over desegregation and community control. As such, it never achieved the kind of broad and deep political momentum that it would have needed to really push and alter school practice. But it did create a series of assessments and a policy template that would be used and revived when standards-based reform gained political momentum in the 1980s and 1990s. It served as a bridge between the district level rationalization of the Progressive Era and the modern state and federal accountability movement. 


\section{S TO THE PRESENT: COMPLETING The RATIONALIZATION OF AMERICAN SCHOOLING}

The third and final school accountability movement began in the 1980s and has continued through the present, and it too was launched by a famous report questioning the quality of American schooling. In this case, a report of the National Commission on Educational Excellence, A Nation at Risk, famously declared the American school system a "rising tide of mediocrity" that imperiled the nation's economic future. In support of its case, it cited a variety of academic indicators, most notably high levels of illiteracy, poor performance on international comparisons, and a steady decline in SAT scores from 1963 to 1980 . Quoting analyst Paul Copperman, the report claimed that this would be the first time in the history of the country that the educational skills of one generation would not be equal to those of their parents. Contrasting this declining educational picture with the centrality of skills and human capital in the knowledge-based post-industrial economy, the report linked the future of the nation's international economic competitiveness to the reform of its educational system (National Commission on Educational Excellence 1983).

It is difficult to overstate the impact of A Nation at Risk. The U.S. Government Printing Office received more than 400 requests for copies in a single hour the following day and distributed more than six million copies over the course of the next year. The press interest was insatiable: The Washington Post published almost two articles per week on A Nation at Risk in the year following the report's release. ${ }^{35}$ More than 250 state commissions (an average of 5 per state!) were created to analyze state education policies and make recommendations for action.

Looking back two decades later, a series of essays assessing the report's impact suggested that the conventional wisdom was that it had stimulated the movements for standards-based reform at both state and federal levels in the 20 years that followed (Gordon 2003, see also Author 2006). 
By polemically documenting the failings of American schooling, and linking this crisis of educational quality to economic concerns, A Nation at Risk both stimulated action and defined the educational problem as centrally an economic one.

The key to this movement was that A Nation at Risk had generated a powerful and multifaceted constituency for change. By framing the problem as an urgent economic one, it raised the salience of education for governors, state legislators, and business groups, each of which became much more involved in the educational arena. While the policy proposals around standards were a virtual replay of what had been suggested during the late 1960s, the politics this time were entirely different, as a much more powerful constituency was now backing the movement (see Author 2011).

For liberals, school accountability promises standardization in the sense of greater equity - the hope is to diminish the variation in school quality across poorer and richer areas. Data, particularly disaggregated data, will shed light on the failings of schools to serve minority students; and this information, it is hoped, will lead to a greater infusion of resources or improved practice. At the same time, while moving towards equity goals, school accountability is a technocratic solution that does not fundamentally upset the geographic distribution of advantage; timid politicians can take small steps towards equity without fundamentally threatening advantaged suburban constituents. ${ }^{36}$

For conservatives, the promise is less in standardizing practice and more in the hopes of accountability. Conservatives repeatedly stressed the importance of accountability to ensuring that the school system is delivering properly for the money spent on it. Particularly in recent years, the growth of teachers unions and their support for the Democratic Party have further spurred conservative desires to hold the educational establishment or "blob" accountable for their 
results. In this respect, conservative support for accountability is in part a response to the growing power of teachers as a political force. Some conservative have also seen accountability as a way for Republicans to "issue trespass" on an issue that has traditionally been in the Democratic column. ${ }^{37}$

Civil rights advocates and business groups have also been unlikely allies in the most recent rounds of standards-based reform. While not all civil rights groups have supported the reforms, those who have see in the reforms a way of making schools, particularly those that house poor and minority students, respond to external policies which have had little impact on their practice. For example, the Citizens Commission on Civil Rights released a report that sharply criticized the lack of implementation of the 1994 ESEA. Arguing that these states were subverting the intention of the law, the Commission noted: "Many states and local officials have received the impression that the new Title I is largely a deregulation law that will free them from bothersome federal conditions, and have failed to understand that the tradeoff in the law is higher standards and accountability for results." 38 Business groups, for their part, have also advocated for standards through the Business Roundtable, with the rationale that economic competitiveness is largely built on the backs of more highly skilled workers. While business groups and civil rights groups usually lie on opposite sides of the partisan divide, both have supported standards and accountability as a mechanism of seeking to direct schools to improve students with higher levels of skills.

The result has been a landslide of political support for standards and accountability in recent decades. Forty-two states had embraced standards before they became a part of federal law through the Elementary and Secondary Education Act in 1994. No Child Left Behind passed with overwhelming support from both House and Senate in 2001. Everyone from Bill Clinton 
and Edward Kennedy on the left, and George W. Bush and John Boehner on the right have at one time been strong champions of standards and accountability. The cleavages have been less partisan and more institutional, arraying not left against right, but rather those seeking to create systemic change from the center against those in the field who sought to resist it.

But where did standards-based reform come from? Yet again, those who sought to reform education turned to an external field for an approach to rationalization, this time drawing on management theorists. In this round, no fewer than three different sets of ideas vied for control.

The first vision drew on management theorists who, ironically, were trying to move away from the command and control structures created during Taylor's age. The work of the management theorists, including Edward Deming, Peter Drucker, and, Reinventing Government gurus David Osborne and Ted Gabler (1992) argued the large bureaucracies formed in the industrial age were anachronistic in a rapidly moving, consumer-driven, information-age economy. Granting greater power to front-line workers would allow them to respond more quickly to changing circumstances. Front-line workers not only have more information about local conditions; granting them greater authority would also improve morale, generate ownership among employees, increase commitment and raise productivity. In terms of education reform, this would mean that schools should be governed by a structure that was "tight on ends and loose on means," meaning that government would hold schools accountable for producing results, but would leave them free to devise the means. In 1986, the National Governors Association produced a document Time for Results, that embraced this very "horse trade" and many continue to see it as the governing principle of the standards movement (Carnegie 1986).

The second vision was authored by Mike Smith and Jennifer O'Day, and it aimed to rationalize the entire system but for professional purposes. Smith and O'Day (1991) were wary 
of the idea that schools, if given freedom to innovate, would produce needed change at scale. Instead, they proposed to organize the entire system around standards: standards would define what students would learn, what teachers should be able to do, how teacher preparation institutes should aim their efforts, and how professional development efforts should be oriented. Smith and O'Day, a professor and graduate student at Stanford, were sympathetic to professional models of reform - they wanted teachers to teach using the most advanced methods available in the fieldbut they also shared the systematizing instincts of the Taylorists, in that they wanted to use standards to create a standardization of practice across the nation's many schools.

The third vision is the one that has prevailed in No Child Left Behind. If the Smith and O'Day vision was one of collective professional responsibility, the alternative view has been one that has emphasized lay accountability. In this view, the problem is less in what teachers' do not know and more in the lack of incentive motivating them to act. Prominent conservative Chester Finn laid out this view in his 1991 book titled, not coincidentally, We Must Take Charge. Finn emphasized that the primary problem of the system was that incentives were not designed around results. He quoted favorably a line by then Secretary of Education Lamar Alexander: "Teaching is the only profession in which you are not paid one extra cent for being good at your job." Painting with a broad brush, Finn argued that schools are like other public sector enterprisesslow, inefficient and focused more on not rocking the boat than on creating innovative practice. ${ }^{39}$ Underlying this range of arguments is a view of human nature as largely motivated by external incentives: "When it comes to academic learning, I believe that external consequences are the main determinant of how hard most of us work and how much we accomplish." ${ }^{40}$ In this view, using data to enforce accountability to the public is the key to system improvement. 
All three of these visions have made some inroads in the years between 1986 and the present, and the standards and accountability movement has drawn support from people who believe in each of them. But No Child Left Behind represents the triumph of the third view, which is closest to original Taylorist precepts. The rate of improvement expected in No Child Left Behind reflects legislators' impatience with the failings of educators, and the system of escalating consequences for failing schools is consistent with the motivational view of lay accountability. The requirements for annual testing have led to the use of multiple-choice off the shelf tests, contrary to the hopes of those like Smith and O'Day who hoped that more complex assessments could spur more advanced methods of teaching.

The triumph of the lay accountability view is perhaps not surprising when viewed within the broader political climate of the times. The post-Reagan period has been one which has featured high levels of skepticism of the efficacy of government and renewed emphasis on ensuring that every public dollar is well spent. In such a climate, lay accountability views are consistent with conservative views of the need to hold public sector employees accountable, and are also attractive to middle of the road Democrats who seek to shed the "tax and spend label" and demonstrate their populist bona fides by ensuring that government employees deliver the return that the public expects. In a period which featured declining trust in government and rising neoliberalism, it is not surprising that efforts to rationalize schools and hold them accountable to the lay public have found a variety of political champions.

Opposition to the lay view of accountability has again come from teachers and schools, who have yet again argued that quantification elevates the measurable over the meaningful, that schools share with society responsible for student outcomes, and that the expected rates of progress are not realistic. But from 1983 to the present, these objections have been largely 
pushed to the side, as central actors have pushed to rationalize the system from the top. Only when faced with the prospect of 70 percent or more of schools designated as failing under NCLB has the Obama administration finally begun to change course by offering waivers to states that would allow them to opt out of No Child Left Behind. No Child Left Behind completed the rationalization of schooling nationwide, but it has proven unable to achieve the results its proponents (from the Progressives to the present) had promised.

\section{AN IMPORTANT UNDERLying STRUCTURAL REALITY: The Organization OF EdUCATION AS a Bureaucratic Hierarchy Rather Than a Domain of Professional Control}

If the underlying pattern of each of these movements is one of ideas sparking a political movement for external accountability, there are also some underlying structural realities which can help us to understand why such similar ideas have been so repeatedly alluring. Among them are: 1) the way in which a highly decentralized system with a highly unequal social geography and weak welfare state produces highly heterogeneous outcomes which strengthened the case for efforts to create greater standardization; 2) the ways in which technocratic solutions promise to improve outcomes without taking on more politically divisive questions of distributive justice; and 3) the way in which education was organized into a bureaucratically-administered hierarchy rather than a field of professional control, a form which has proven to be particularly conducive to the kind of principal-agent claims that are at the essence of school accountability regimes. Since the first two points have been more extensively covered in the literature, I focus here on the last point, the way in which the profession was organized. ${ }^{41}$

School teaching, like the similarly feminized semi-professions of nursing and social work, never developed the characteristics that defined the more traditional professions (Etzioni 1969, Lortie 1975). Primary and secondary school teaching in the United States does not possess 
the characteristics that are common in more fully professionalized fields: lengthy training, social closure over who can enter its ranks, or a pedagogical knowledge base that is widely respected by the public. Initially a career option primarily for women before they had children, teaching in the Progressive Era was incorporated within a bureaucratic-management model in which teachers reported directly to administrators and established little professional control of their own. While loose coupling (Meyer and Rowan 1977) preserved some professional autonomy at the classroom level, teachers have not taken collective control of their practice and remain institutionalized within a hierarchical bureaucracy. Teachers were also under the thumb of the state from the start, which presumably somewhat weakened their ability to assert independent professional power (Krause 1996, Light 1995). The result has been that, in comparison to stronger professions that came to take control of their own affairs, the way that education was institutionalized has left the field particularly vulnerable to administrator-led rationalization.

At the same time, it is possible to imagine a stronger profession of teaching within the state, and it is historical factors that can explain the particularly weak institutionalization of American teaching, in particular the circumstances of its organizational imprinting (Stinchcombe 1965). Part of this occurred for reasons previously discussed - a cadre of elites in the Progressive Era who believed in a Taylorist model of management successfully were able to turn a diffuse set of one room schoolhouses into a "one best system" of bureaucratic efficiency under the thumb of a CEO-like superintendent (Tyack 1974). But another set of actors were also important (and influenced many of Tyack's lay reformers): university departments of education and the models of educational administration that they propagated.

At the turn of the century, the field of education was only just emerging as a university subject, usually housed as a sub-discipline within philosophy departments. Faculty within many 
of the top flight universities considered the study of education not worthy of the title of either art or science, and were particularly skeptical that the largely female dominated field of teaching was worthy of the professional training accorded to male dominated fields of law, medicine or engineering. ${ }^{42}$ Facing this climate of skepticism, deans and department chairs of education like Edward Cubberley (at Stanford), James Earl Russell (at Columbia), and Hubbard Judd (at Chicago) moved to shift the study of education away from its diffuse humanistic focus and towards a more practical and specialized view of educational administration grounded in emerging findings from science. At Teachers College, Russell became "one of the foremost advocates for a professional science of education. He believed that professional knowledge could enhance teaching, an improvement which would, in turn, foster a more generous attitude toward education among both academics and the public at large."43

The training of administrators provided an opportunity for education departments to train a new class of male professionals whose role was widely being discussed as equivalent to that of a CEO. This offered a way for education departments to see themselves more on a par with professions like medicine, law and engineering, and eliminate the stigma that came with training a largely feminized profession. As Cubberley described it in his classic textbook, Public School

\section{Administration:}

"School supervision represents a new profession, and one which in time will play a very important part in the development of American life. In pecuniary, social, professional and personal rewards it ranks with the other learned professions, while the call for city school superintendents of the right type is today greater than the call for lawyers, doctors or ministers. The opportunities offered in this new profession to men of strong character, broad sympathies, high purposes, fine culture, courage, exact training and executive skills... are today not excelled in any of the professions, learned or otherwise."44

Cubberley continued by suggesting that superintendents should be expected to complete college and one year of graduate school, and many should continue to the Ph.D., while teachers needed 
only a high school education and a two-year training program. For a university discipline seeking to gain its footing, developing a science of school administration that required extensive training and that would be overseen by a largely male administrative corps provided a way for education departments and schools to claim greater equivalence with higher status fields like medicine and law. ${ }^{45}$

In so doing, they embraced a hierarchical and differentiated model of research, administration, and implementation that provided much of the template for the accountability movement. A largely quantitative and statistical research program would be carried out by the scientists in the university, who would convey it to the highly trained school administrators, who would implement it, with teachers as the final links in the chain at the bottom of the totem pole. As testing expert Edward Thorndike encapsulated this hierarchical approach in his 1906 text The Principles of Teaching: "It is the problem of the higher authorities of the schools to decide what the school shall try to achieve and to arrange plans for schools' work which will attain the desired ends. Having decided what changes are to be made they entrust to the teachers the work of making them." ${ }^{26}$ It is not surprising that, with this template in mind, what emerged was a program of scientific efficiency that allowed superintendents to supervise, evaluate, and compare the work of different teachers and schools, with the goal of using comparative data and research to establish best practices for improving performance and the efficiency of administration.

John Dewey provided an alternative model of the organization of schooling and research, and the failure of this model reveals the strength of institutional imperatives pulling in the opposite direction. In Dewey's famous laboratory school, the school itself served as a primary opportunity for research. In Dewey's view, there was no need to partition the role of researcher and teacher, arguing instead that both were interested in the same subject-improving learning. 
Rather than have "one expert dictating educational methods and subject-matter to a body of passive, recipient teachers," Dewey advocated "the adoption of intellectual initiative, discussion, and decision throughout the entire school corps." But while Dewey's ideas were widely discussed, his model of research as a function to be shared between researchers and schoolteachers was rejected by university education departments, which were seeking to elevate themselves precisely by distancing themselves from teachers. As Ellen Lagemann puts it: "His position was very much at odds with the hierarchy then developing among educational institutions, a hierarchy in which mostly male university scholars of education would generate the knowledge needed by mostly male school administrators, who would, in turn, be responsible for dictating and supervising the instructional methods to be used by teachers in schools, especially the mostly female teachers involved at the elementary levels." ${ }^{47}$

This hierarchical structure has remained in place in the years since, and has left teachers with little collective ability to respond to movements seeking to impose principles of rationalization. In other work, I compare movements for accountability in K-12 education with similar movements in higher education and find that the latter have been much weaker because of the way that higher education developed a guild-like structure where faculty retain considerable collective determination over the direction of their core professional activities (Author 2011). ${ }^{48}$ In contrast, in K-12 education, teachers responded to their lack of power by following an industrial union model, which, while increasing their pay, working conditions and political power, actually reaffirmed the distinction between labor and management that technocratic logic rests upon. Efforts by teacher union leaders like Albert Shanker, Bob Chase, Adam Urbanski and others to move away from this hierarchical model and give teachers more responsibility for their practice have been largely unsuccessful in changing this overall structure. 
Administrators have been largely unwilling to yield power, and teachers have been reluctant to move away from the industrial unionism model and the protections it affords (see Author 2006 for more details).

Given this institutional structure, public school administrators, for their part, have largely been carriers of these external technocratic logics, as they sit in essentially middle manager positions between teachers and schools and the politicians who oversee them. Districts today in particular are awash in a range of management positions, like chief accountability officers, whose central function is the development of these rationalizing logics. While accountability movements do not pose the kind of jurisdictional competition that Abbott (1988) chronicles, they do present something potentially just as significant - the widespread embrace of an external technocratic logic by many of the most powerful people within the profession.

If resistance and capitulation are the two most visible responses to technocratic logic, there is also a third option which some leaders of the profession have sought to pursue. These leaders have their own critique of the failings of the educational field - that precisely because it was not institutionalized into a stronger profession it has weak norms of collective practice to guide school improvement. These leaders share the desire of the Taylorists to "systemic reform" (Smith and O'Day 1991), but they are much more committed to these systems being guided by professional knowledge about teaching and learning. Their diagnosis of the problem similarly relates less to the need to motivate teachers to work harder for improvement, and more to the idea that increasing their knowledge and skills is the key to progress in schooling (Elmore 2004). In essence, there are two seemingly similar, but in fact highly divergent views of "standards" as the key to reform: the currently prevailing "hard" version which emphasizes the need for competition, seeks to hold professionals accountable to the public, and tries to exert pressure to 
change a moribund public system; and a "softer" view which emphasizes the need for professional collaboration, wants the public to gain enough confidence in the field to defer to professional knowledge, and sees increased the knowledge and skill of practitioners as the key to successful reform. The outcome of this struggle is the difference between on the one hand, the educational field again being penetrated by an external technocratic logic, and, on the other, the leaders of the field effectively using the external desire for system-wide change to help professionalize the field. ${ }^{49}$

\section{DISCUSSION AND CONCLUSION}

The most recent standards and accountability movement is actually the third movement of its type in the $20^{\text {th }}$ century. While the context of these accountability movements have gradually shifted upward from local to state to federal, in their ethos and theory of action they share similar characteristics to the process of rationalization that Weber so presciently identified.

This recurrent instinct to rationalize schools is not easily explained by partisan or interest groups theories. A wide range of different actors have supported the reforms, including liberals and conservatives, civil rights advocates and business groups, state departments of education and university departments of education. There is no one set of initiating actors that was important in all three of the cases. Business groups, who one might imagine would be lead actors, took a back seat to political actors in the most recent reforms, and were not involved in the 1960s reforms. Other theories which emphasize that conflicts of values among the public might lead to this kind of cycling of reforms are plausible, but are vague and do not offer a specific explanation for the recurrence of accountability-centered reforms. 
The penchant for rationalizing schools is better understood as a process by which a technocratic logic comes to penetrate the educational sphere. Looking across the cases we see a recurring pattern: schools are declared to be in crisis by an authoritative source; a high status epistemic community offers a solution premised on what they claim are scientifically validated premises of management practice; a wide variety of actors external to the schools back such a logic because it gives them a way to control and create greater standardization of schools from the outside, over the objections of teachers who resent accountability and see aspects of their practice being compromised; these objections are unable to carry the day because of the weak status and institutionalization of a highly feminized profession. Despite other major differences in the periods under study, these patterns remain remarkably consistent across periods.

This theory can explain the distinctive political cleavages created during episodes of accountability-centered reform. There is no one recurring lead proponent of the reforms because technocratic logic appeals to a wide variety of external actors for different reasons. Liberals see in it a way to create greater equalization of school process across a highly decentralized landscape. Conservatives see in it a way to assure that public dollars are being spent efficiently, and to motivate a recalcitrant sector for reform. The cleavages of rationalizing movements are less left vs. right than top vs. bottom, or outsiders vs. insiders. The commensurating logic of measurement-driven change unites those who are outside of schools and seeking to create change within them against teachers who are being held to account.

While business groups have not been the lead actors in each round of reforms, business logic is common across the cases. Higher status epistemic communities, often tied to industry or using ideas derived from industry, have repeatedly been able to overwhelm a weakly institutionalized professional field. Particularly in the Progressive Era and the present, these 
ideas from the business community have resonated widely with policymakers and the broader public. The weakly professionalized education sector has proven no match for these higher status epistemic communities, and many educators, particularly in administrative positions, have ended up implementing logics imported from other sectors. While educational accountability has previously been discussed largely in terms of equity, issues of professional jurisdiction are also at stake.

One obvious question is why these movements have had to recur, given that they were mostly fairly successful in accomplishing their aims. The most straightforward answer is that they take place at different institutional levels: the Progressive Period created an early system of standards, tests and accountability at the district level; the reformers of the late 1960s and early 1970s sought to extend these efforts to create state standard-based reform; and then the reformers from the 1980s to the present created a much more robust system of state-level accountability, which in turn provided the foundation for federal reform through No Child Left Behind. It is less that the previous movements were defeated and more that the newer movements sought to build upon and supersede earlier ones by extending the reach of school accountability movements at higher levels.

It is worth noting that while rationalizing reforms have been recurrently popular throughout the United States over the past century, there is no iron law of school rationalization, and there are other approaches which have also gained favor. School accountability approaches at different times have had to contend with movements for desegregation, community control, and a variety of market-based strategies, among many others. Despite the claims of reformers that standards would commensurate all of the important goals of schooling, there have been periods in which the state-centered scientific management approach has not been at the top of the 
agenda, as shifts in values have prioritized other approaches to thinking about improving schooling (Labaree 1997). The most recent decision of the Obama administration to let states apply for waivers that would allow them to opt out of key provisions of No Child Left Behind may be an indication that the current emphasis on state and federal school accountability is finally beginning to run its course. At the same time, the growing momentum behind Common Core standards may presage yet another round of external standards-driven change.

For teachers, the implication of this analysis is that teaching needs to strengthen its professional core if it does not want to be repeatedly vulnerable both to external movements for accountability and the infusion of external technocratic logics. The recent movements to appoint those with little to no education experience to run major school systems are only the most current manifestation of a century-long pattern. Whether fair or not, unless educators develop the characteristics associated with more developed professions - a robust knowledge base, a method of selecting, training and licensing that produces skilled practitioners, and ongoing standards for monitoring practice - it will remain at the whim of external actors and logics seeking to control the field.

One hope of such an approach would be to change the relationship between schools and policymakers. Schools and teachers are weak actors, as this essay has emphasized, with respect to policy decisions about school accountability, in part because they lack the collective credibility that comes with a stronger profession. But they have had considerable impact in the implementation of school accountability: as other studies have suggested, when the aims of policymakers outstrip the capacity of local actors to realize them, those actors have a variety of ways of using their power as street-level bureaucrats to resist, dilute, game, become overwhelmed, or otherwise act in ways that are contrary to what policymakers hope when they 
enact the policy (Elmore 2004, Booher-Jennings 2005). One aspiration of a more professionalized system is that policymakers and schools would not see one another as enemies, and hence could work more collaboratively to develop policies that would enable teachers, rather than being actively resisted by the people who are expected to implement them.

Such an approach is also needed because the literature on implementation suggests that the task of teaching and the organization of the school system are fundamentally impervious to top-down rationalization, especially if the goal is to teach to high-level skills. ${ }^{50}$ American schools are famously organized into loosely coupled systems, and classrooms, especially good classrooms, are staffed by able teachers who are able to successfully navigate and manage the literally hundreds of decisions that need to be made over the course of even one class (Huberman 1993). For these reasons, efforts to rationalize teaching from above have repeatedly not achieved what its proponents have promised; as in many fields with complex work, a more professional approach that focuses on developing usable knowledge, strengthening training, providing clinical opportunities for learning, and then relying on the established skill of these practitioners is in the long run the more promising approach (Mehta, Bryk, and Gomez 2012).

What is particularly complicated here is that while a technical analysis of the needs of teaching suggests the need for a more professional approach, the political winds over the past 3040 years have been shifting against the notions of professional control. Scholars of the professions have noted that the highpoint of guild power of the major professions was the mid 1960s, and that market critiques and populist attacks have weakened its hold in the years since (Krause 1996). The challenge for K-12 education in this environment is to try to draw upon the virtues of professionalism - developing expert knowledge in their fields, working within a normative code, and holding all practitioners to the standards of the field-while at the same 
time navigating broader political waters that are much more skeptical of the whole notion of professional control.

Emerging international evidence dovetails with this analysis and suggests that a more professional approach would not only increase teacher autonomy but also improve student outcomes. While this research is only in its early stages, the initial conclusions are supportive of the idea that professionalizing teaching is an important next step in improving outcomes. As OECD PISA Director Andreas Schleicher and Marc Tucker summarize lessons from comparative analysis of the PISA: "The education development progression is characterized by a movement from relatively low teacher quality to relatively high teacher quality; from a focus on low-level basic skills to a focus on high-level skills and creativity; from Tayloristic forms of work organization to professional forms of work organization; from primary accountability to superiors to primary accountability to one's professional colleagues, parents and the public; and from a belief that only some students can and need to achieve high learning standards to a conviction that all students need to meet such high standards." 51 Policy in the United States has made this shift with respect to its ends - all students need to achieve to high levels - but its means are still grounded in trying to tighten the screws on a Progressive era Taylorist bureaucracy. If the goal in the long run is not simply to hold schools accountable but to get them to consistently produce at higher levels of practice, the United States will need to move away from its recurring emphasis on scientific methods of control from above and embrace the more professional path that is characteristic of top performing nations. 


\section{Notes}

${ }^{1}$ Some commentators have seen the latter two movements as part of one long move towards educational accountability that began in the 1960s. In one sense, this is true - that the states standards movement of the late 1960s and early 1970s led into the minimum competency testing movement in the later 1970s, which in turn led into a more developed state standards movement in the 1980s. However, as will be documented below, the state standards efforts in the 1960s and early 1970s were only marginally successful at building a needed political constituency, and by the end of the 1970s there was little enthusiasm for large-scale school reform at the state and particularly federal levels, especially among Republicans. A Nation at Risk then launched a third round of school reform that built on some of the policy templates created in the 1960s, but this time with a much wider set of political backers. Given that the purpose of this article is to understand how educational accountability movements are launched, it makes sense to treat the two more recent cases as separate episodes, as each had their own history, set of initiating events, and set of actors involved. The latter was also much more successful than the former.

${ }^{2}$ In the Progressive period, the main shift was from one room schoolhouses to urban systems.

${ }^{3}$ Obviously there were minority elements within both parties that resisted accountability movements. In the most recent round, the most notable critics within the parties have been states rights conservatives (who see in accountability unwarranted expansion of state and federal power), libertarian conservatives (who see it as unwanted bureaucracy), and some liberals (who see it as overly focused on testing to the neglect of resources or other supports that would improve the lives of high poverty students). For more details on these political cleavages, see Author (2006).

${ }^{4}$ Callahan (1962: 3).

${ }^{5}$ Hofstadter (1955: 185).

6 Tyack (1974: 151).

${ }^{7}$ Leonard Ayres published his 1909 book, Laggards in Our Schools, contending that schools were squandering resources by having students, particularly immigrant and minority students, repeat grades and eventually drop out. Ayres classified students as "retarded" if they were over age for their grade level, and constructed an "index of efficiency" that measured how effectively schools were moving their students along, and how much was being wasted on repeaters. While, in the $19^{\text {th }}$ century, holding children back had been seen as a sign of high standards, in the new context of an expanded student population and limited resources, it was seen as a waste of valuable tax dollars.

${ }^{8}$ Giordano (2005: 55).

${ }^{9}$ Tyack (1974: 128).

${ }^{10}$ Callahan (1962: 159). Although later scholars have heavily scrutinized Callahan's arguments on the connections between business methods and school administration, his basic conclusions have emerged largely unscathed (Eaton 1990).

${ }^{11}$ John Franklin Bobbitt, quoted in Callahan (1962: 82).

${ }^{12}$ Callahan (1962) on the 1916 data; for the 1934 data see Resnick (1980).

13 Callahan (1962: 43). See Porter (1995) for examples of how cost-benefit thinking has been applied across a variety of (non-economic) dimensions.

${ }^{14}$ Kliebard (1995: 76)

15 Tyack (1974: 127).

16 Tyack (1974: 147-167).

${ }^{17}$ Murphy (1990: 23-45). While in this piece I emphasize the desire for order and standardization as the impetus for reformers, and teachers under-professionalization as the reason for their inability to resist, it is also possible to see the Progressive Era efficiency movements as a struggle for control between increasingly powerful superintendents and newly organized teachers. In this reading, even if the initial impetus for rationalization was the muckraking by Rice and others, the ongoing struggle is one in which administrative control seeks to grow to resist increasing efforts at teacher control. I thank an anonymous reviewer for suggesting this alternative interpretation.

${ }^{18}$ Callahan (1962: 121). 
${ }^{19}$ Kennedy is quoted from the transcript of the hearing on the ESEA, Senate Education Subcommittee, $89^{\text {th }}$ Congress. Quotation is accessed online at: http://drcookie.blogspot.com/2008/06/robert-f-kennedy-at-1965-hearingsabout.html

${ }^{20}$ Barbara J. Kiavat, “The Social Side of Schooling,” Johns Hopkins Magazine, April 2001.

${ }^{21}$ Coleman (1972): 149-150.

${ }^{22}$ Browder (1975: 1).

${ }^{23}$ Wise (1979: 12). Also see Wise (1979) for definitions of these various terms.

${ }^{24}$ Lessinger (1970: 10).

${ }^{25}$ Lessinger (1970:11).

${ }^{26}$ James (1976/1968: 40-41).

${ }^{27}$ Gene I. Maeroff, "Accountability Plan Angers Teachers, With Many Foreseeing Threat to Jobs," New York Times, July 6, 1974, pg. 20.

${ }^{28}$ Bowers (1972: 29).

${ }^{29}$ See Educational Testing Service (1973), Hawthorne (1974), and Hawke et al (1975).

${ }^{30}$ Educational Testing Service (1973).

${ }^{31}$ Hawke et al. (1975: 27).

${ }^{32}$ Schattschneider (1960).

${ }^{33}$ Hawke et al. (1975).

${ }^{34}$ Murphy and Cohen (1974).

${ }^{35}$ Guthrie and Springer (2004: 12).

${ }^{36}$ McGuinn (2006).

${ }^{37}$ Of course, some states rights conservatives have opposed testing for its role in expanding federal power, and some libertarian conservatives have seen it as expanding bureaucracy in place of needed markets. For more details on these schisms, see Author (2006).

${ }^{38}$ Citizens' Commission on Civil Rights (1998: 2).

${ }^{39}$ Finn (1991: 147-149).

${ }^{40}$ Finn (1991: 125).

${ }^{41}$ On the ways in which decentralization has both inspired and frustrated efforts for greater centrally-driven standardization of outcomes, see Cohen and Moffitt (2009). On the ways in which policymakers use technocratic logics to avoid discussions of distributive justice, see Orfield and Yun (1999) and Kozol (2005).

${ }^{42}$ As Harvard President Charles Eliot said, speaking for the Harvard faculty, "The faculty in common with most teachers in England and the United States feel but slight interest or confidence in what is usually called pedagogy." 42 Similar attitudes were found at Stanford, where the Department of Education survived only due to its support from Stanford President David Starr Jordan; Jordan told Cubberley upon his arrival in 1898 that, if the decision had been left to the faculty, the department would have been abolished entirely. At Columbia, President Seth Low was able to persuade the trustees to bring Teachers College within the umbrella of the university, but, as Dean of Teachers College James Earl Russell put it, not "as a professional school on par with the others...[but] as the stepchild of the University Department of Philosophy and Education” (Lagemann 2000: 63).

${ }^{43}$ Lagemann (2000: 64).

${ }^{44}$ Callahan (1962: 218).

${ }^{45}$ As Joncich and Guthrie (1988: 100) aptly sum it up: "Male teachers who stayed too long in the classroom -in the regular company of women and children - might even raise doubt about their manliness and, therefore, their suitability for dealing with the local power brokers on school boards and in chambers of commerce. Were these the men to save school administration and educational research careers from the threats of feminization, the men able to deal with businessmen and civic leaders in the hurly-burly world of realpolitik? Clearly not. Instead, graduate students in education must be drawn early from their classrooms or recruited from among the graduating seniors of high-status colleges."

${ }^{46}$ Thorndike as quoted in Lagemann (2000: 60).

${ }^{47}$ Lagemann (2000: 51).

${ }^{48}$ While American higher education has had comparatively greater professional power, the claim is not that higher education is always a beacon of professional power nor that it is impervious to state rationalization. The growth of adjunct faculty has significantly eroded the traditional power conferred by faculty governance in American higher education.. Accountability movements of state universities in England reveal that states can impose their reach even 
into stronger professional domains. The claim here is simply that, all else equal, state efforts to impose accountability will be weaker the stronger the profession is that contests them. This is consistent with the framework offered by Krause (1996), who sees a tripartite division between states, markets, and professions, and suggests that which is more powerful in a given place and time is dependent upon specific historical factors.

${ }^{49}$ See also Holmes Group (1986), Carnegie (1986).

${ }^{50}$ I think this is one way to read one aspect of the Cohen and Moffitt (2009) argument.

51 Tucker and Schleicher (2010): 231. 


\section{Bibliography}

Abbott, Andrew. 1988. The System of Professions: An Essay on the Division of Expert Labor. Chicago: University of Chicago Press.

Author. 2010. "From 'Whether' to 'How': The Varied Roles of Ideas in Politics." In How Ideas Matter: Reframing Political Research, eds. Daniel Beland and Bob Cox. Oxford: Oxford University Press.

Author. 2011. "How Paradigms Create Politics: The Transformation of American Educational Policy, 1980-2001." Revise and resubmit at the American Journal of Sociology.

Author. 2011. "Does Professional Status Affect Demands for Accountability? Comparing K-12 and Higher Education." Revise and resubmit at American Journal of Education.

Baumgartner, Frank and Bryan D. Jones. 1993. Agendas and Instability in American Politics. Chicago: University of Chicago Press.

Beland, Daniel and Jacob S. Hacker. 2004. "Ideas, Private Institutions, and American Welfare State 'Exceptionalism': The Case of Health and Old-Age Insurance in the United States, 1915-1965." International Journal of Social Welfare 13(1): 42-54.

Booher-Jennings, Jennifer. 2005. "Below the Bubble: 'Educational Triage' and the Texas Accountability System.” American Educational Research Journal 42: 231-268.

Bourdieu, Pierre and Lois Wacquant. 1992. An Invitation to Reflexive Sociology. Cambridge: Polity Press.

Bowers, C.A. 1972. "Accountability From a Humanist Point of View." In Accountability in American Education, Frank Sciara and Richard Jantz, eds, pp. 25-32. Boston: Allyn and Beacon.

Browder, Lesley. 1971. Emerging Patterns of Administrative Accountability. Berkeley: McCutchan.

1975. “Who's Afraid of Educational Accountability.” Denver: Cooperative Accountability Project.

Callahan, Raymond. 1962. Education and the Cult of Efficiency. Chicago: University of Chicago Press.

Campbell, John L. 2002. "Ideas, Politics, and Public Policy.” Annual Review of Sociology 28: 21-38.

Carnegie Forum on Education and the Economy, Task Force on Teaching as a Profession. 1986. A Nation Prepared: Teachers for the $21^{\text {st }}$ Century. New York: Carnegie Forum.

Chubb, John E. and Terry M. Moe. 1990. Politics, Markets, and America's Schools. Washington: Brookings.

Citizens' Commission on Civil Right. 1998. Title I in Midstream: The Fight to Improve Schools for Poor Kids. Washington: Citizens' Commission on Civil Rights.

Cohen, David K. and Susan L. Moffitt. 2009. The Ordeal of Equality: Did Federal Regulation Fix the Schools? Cambridge: Harvard University Press.

Coleman, James. 1972. "The Evaluation of Equality of Educational Opportunity." In On Equality of Educational Opportunity, eds. Frederick Mosteller and Daniel P. Moynihan. New York: Basic Books.

Cuban, Larry. 1990. "Reforming Again, Again, and Again.” Educational Researcher 19:(1): 3-13. 
Cuban, Larry. 1993. How Teachers Taught: Constancy and Change in America's Classrooms, 1890-1990. New York: Teachers College Press.

Cubberley, Ellwood P. 1916. Public School Administration. Boston: Houghton Mifflin.

Davies, Scott. 1999. "From Moral Duty to Cultural Rights: A Case Study of Political Framing in Education." Sociology of Education 72(1):1-21.

. 2002. "The Paradox of Progressive Education: A Frame Analysis" Sociology of Education 75(4):269-286.

Educational Testing Service. 1973. "State Testing Programs.” Princeton: Educational Testing Service.

Elmore, Richard F. 2004. School Reform from the Inside Out. Cambridge: Harvard Education Press.

Espeland, Wendy and Mitchell Stevens. 1998. "Commensuration as a Social Process." Annual Review of Sociology.

Etzioni, Amitai. 1969. The Semi-Professions and Their Organization: Teachers, Nurses and Social Workers. New York: Free Press.

Ferree, Myra Marx, William A. Gamson, Jürgen Gerhards and Dieter Rucht. 2002. Shaping Abortion Discourse: Democracy and the Public Sphere in Germany and the United States. New York: Cambridge University Press.

Finn, Chester. 1991. We Must Take Charge: Our Schools and Our Future. New York: Free Press.

Friedland, Roger, and Robert R. Alford. 1991. "Bringing Society Back In: Symbols, Practices, and Institutional Contradictions." In The New Institutionalism in Organizational Theory, Walter Powell and Paul DiMaggio, eds, pp. 232-266. Chicago: University of Chicago Press.

Fuhrman, Susan H. 1999. "The New Accountability," CPRE Policy Brief. Philadelphia: University of Pennsylvania.

Gladwell, Malcolm. 2003. "Making the Grade." New Yorker, September 15.

Giordano, Gerald. 2005. How Testing Came to Dominate Schools. New York: Peter Lang.

Gordon, David T., ed. 2003. A Nation Reformed? American Education 20 Years After A Nation at Risk. Cambridge: Harvard Education Press.

Guthrie, James W. and Matthew G. Springer. 2004. “A Nation at Risk Revisited: Did 'Wrong' Reasoning Result in 'Right' Results? At What Cost?” Peabody Journal of Education 79(1): 7-35.

Hall, Peter A. 1989. "Conclusion: The Politics of Keynesian Ideas.” In The Political Power of Economic Ideas: Keynesianism Across Nations, ed. Peter Hall, 361-391. Princeton: Princeton University Press.

- 1993. "Policy paradigms, social learning, and the state: The case of economic policymaking in Britain." Comparative Politics 29: 275-296.

Hawke, Sharryl et al. 1975. "State Accountability Activities and the Social Studies: A Nationwide Survey, A Proposed General Accountability Model and Some Guidelines." Boulder: ERIC Clearinghouse for Social Studies/Social Science Education and Social Science Education Consortium." 
Hawthorne, Phyllis. 1974. "Legislation by the States: Accountability and Assessment in Education, Report Number 2." Denver: Cooperative Accountability Project.

Hofstadter, Richard. 1955. The Age of Reform. New York: Knopf.

Hofstadter, Richard. 1955. The Age of Reform. New York: Knopf.

- 1963. Anti-Intellectualism in American Life. New York: Knopf.

Holmes Group. 1986. Tomorrow's Teachers: The Report of the Holmes Group.

Huberman, Michael. 1993. "The Model of the Independent Artisan in Teachers' Professional Relations." In Teacher's Work: Individuals, Colleagues, and Contexts, eds. Judith Little and Milbrey McLaughlin. New York: Teachers College Press.

James, Thomas. 1971. “The New Cult of Efficiency and Education.” In Browder (1971), pp. 39-46.

Joncich, Geraldine and James W. Guthrie. 1988. Ed School: A Brief for Professional Education. Chicago: University of Chicago Press.

Kliebard, Herbert M. 1995. The Struggle for the American Curriculum, 1893-1958. New York: Routledge.

Kozol, Jonathan. 2005. The Shame of the Nation: The Restoration of Apartheid Schooling in America. New York: Crown.

Krause, Elliott A. 1996. Death of the Guilds: Professions, States, and the Advance of Capitalism, 1930 to the Present. New Haven: Yale University Press.

Labaree, David F. 1997. "Public Good, Private Goods: The American Struggle over Educational Goals.” American Educational Research Journal, 34:1 (Spring), 39-81.

Lagemann, Ellen. 2000. An Elusive Science. Chicago: University of Chicago Press..

Light, Donald. 1995. "Countervailing Powers: A Framework for Professions in Transition.” In Health Professions and the State In Europe, eds. Terry Johnson, Gerry Larkin and Mike Saks, 25-44. London: Routledge.

Lortie, Dan C. 1975. Schoolteacher; A Sociological Study. Chicago: University of Chicago Press.

MacIntyre, Alasdair. 1984/1981. After Virtue: A Study in Moral Theory. $2^{\text {nd }}$ edition. Notre Dame: University of Notre Dame Press.

Manna, Paul. 2006. Schools In: Federalism and the National Education Agenda. Washington: Georgetown University Press.

McGuinn, Patrick James. 2006. No Child Left Behind and the Transformation of Federal Education Policy, 1965-2005. Lawrence: University Press of Kansas.

Mehta, Jal, Louis Gomez, and Anthony S. Bryk. 2012. "Building on Practical Knowledge: The Key to a Stronger Profession is Learning from the Field." In The Futures of School Reform. Cambridge: Harvard Education Press.

Meyer, Heinz-Dieter and Brian Rowan. 2006. The New Institutionalism in Education.. Albany: State University of New York Press. 
Meyer, John W. and Brian Rowan. 1977. "Institutionalized Organizations: Formal Structure as Myth and Ceremony." American Journal of Sociology 83(2): 340-363.

Murphy, Jerome and David Cohen. 1974. "Accountability in Education: The Michigan Experience." Public Interest 36: 53-81.

National Commission on Excellence in Education. 1983. A Nation at Risk: The Imperative for Educational Reform. Washington: The Commission.

National Governors' Association. 1986. Time for Results: The Governors' 1991 Report on Education Washington: National Governors' Association.

Orfield, Gary and John Yun. 1999. Resegregation in American Schools. Cambridge: Civil Rights Project.

Osborne, David and Ted Gabler. 1992. Reinventing Government: How the Entrepreneurial Spirit is Transforming the Public Sector. Reading: Addison-Wesley.

Perkins, Henry J. 1977. The Imperfect Panacea: American Faith in Education, 1865-1976. New York: Random House.

Pressman, Jeffrey L. and Aaron Wildavsky. 1973. Implementation: How Great Expectations in Washington are Dashed in Oakland. Berkeley: University of California Press.

Ragin, Charles and Howard Becker. 1992. What is a Case? Exploring the Foundations of Social Inquiry. Cambridge: Cambridge University Press.

Rochefort, David A. and Roger W. Cobb. 1994. The Politics of Problem Definition: Shaping the Policy Agenda. Lawrence: University of Kansas.

Schattschneider, E.E. 1960. The Semi-Sovereign people: A Realist's Guide to Democracy in America. New York: Holt.

Smith, Marshall S. and Jennifer O'Day. 1991. "Systemic School Reform.” In The Politics of Curriculum and Testing, eds. Susan H.. Fuhrman and Betty Malen, 233-267. Philadelphia, PA: Falmer Press.

Starr, Paul. 1982. The Social Transformation of American Medicine. New York: Basic Books.

Tucker, Marc and Andreas Schleicher. 2010. "Lessons for the United States," in Strong Performer and Successful Reformers in Education: Lessons From Pisa for the United States. OECD.

Tyack, David. 1974. The One Best System. Cambridge: Harvard University Press.

. 1993. "School Governance in the United States: Historical Puzzles and Anomalies." In Decentralization and School Improvement, eds. Jane Hannaway and Martin Conroy, 1-32. San Francisco: Jossey Bass.

Tyack, David and Larry Cuban. 1995. Tinkering Toward Utopia: A Century of Public School Reform. Cambridge: Harvard University Press.

Weick, Karl. 1976. "Educational Organizations as Loosely Coupled Systems." Administrative Science Quarterly. 21 1-9 (part).

Wise, Arthur. 1979. Legislated Learning: The Bureaucratization of the American Classroom. Berkeley: University of California Press. 